\title{
PENERAPAN TEORI BELAJAR BRUNER DENGAN PENDEKATAN PENDIDIKAN MATEMATIKA REALISTIK DI KELAS III SD MUHAMMADIYAH 9 SURABAYA
}

\author{
Ervayani $^{1}$, Iis Holisin ${ }^{2}$, Shoffan Shoffa ${ }^{3}$. \\ Progam Studi Pendidikan Matematika, FKIP UMSurabaya \\ Erva_yaniums@yahoo.co.id
}

\begin{abstract}
ABSTRAK
Permasalahan dalam penelitian ini adalah nilai harian siswa kelas III SD Muhammadiyah 9 Surabaya yang belum mencapai KKM dan guru yang masih menggunakan metode klasikal dan ceramah. Penelitian ini bertujuan untuk mendeskripsikan Penerapan Teori Belajar Brunner Dengan Pendekatan Pendidikan Matematika Realistik Di Kelas III SD Muhammadiyah 9 Surabaya.

Penelitian ini merupakan penelitian deskriptif kuantitatif, bertujuan untuk mendeskripsikan prestasi belajar siswa, aktivitas siswa, aktivitas guru dan respon siswa setelah penerapan teori belajar Bruner dengan pendekatan pendidikan matematika realistik. Penelitian ini dilakukan di SD Muhammadiyah 9 Surabaya. Subjek penelitian adalah siswa kelas III yang berjumlah 17 dan dibagi menjadi empat kelompok. Pengumpulan data dilakukan dengan teknik tes, observasi, angket dan dokumentasi. Data yang diperoleh dianalisis dengan teknik persentase.

Hasil penelitian menunjukkan bahwa penerapan teori belajar Bruner dengan pendekatan pendidikan matematika realistik dapat meningkatkan prestasi belajar siswa kelas III SD Muhammadiyah 9 Surabaya sebesar 26,22 \%, Aktivitas siswa sebesar 87,4\%, aktivitas keterlaksanaan guru sebesar $91,6 \%$ dan respon siswa terhadap penerapan teori belajar Bruner dengan pendekatan pendidikan matematika realistik sebesar $96,7 \%$.
\end{abstract}

Kata kunci: Pendidikan matematika realistik, teori Bruner.

\section{PENDAHULUAN}

Matematika merupakan salah satu mata pelajaran yang diajarkan pada jenjang pendidikan dasar, pendidikan menengah maupun pendidikan tinggi. Berdasar hasil penelitian Peterson dan Fennema dalam Karim (2011:23 ) di sekolah dasar, bahwa hanya $15 \%$ dari waktu belajar yang digunakan untuk mengembangkan kemampuan berpikir matematis tingkat tinggi, $62 \%$ waktu belajar digunakan untuk mengembangkan kemampuan berpikir matematika tingkat rendah, dan 13\% sisanya untuk kegiatan yang tidak ada kaitan dengan pelajaran matematika. Sehingga penjelasan materi yang diberikan oleh guru seringkali dirasakan sulit bagi siswa di dalam memahaminya. Hal ini disebabkan oleh proses penyajian materi yang tidak sesuai dengan karakteristrik siswa sekolah dasar, apalagi salah satu ciri dari matematika adalah obyeknya bersifat abstrak dan hirarkis yang menyebabkan tingkat kesulitan yang relatif tinggi bagi siswa sekolah dasar. Akibatnya adalah rendahnya prestasi belajar matematika siswa. 
Keberhasilan peserta didik tidak terlepas dari peranan guru dalam proses pelaksanaan kegiatan pembelajaran di kelas. Keberhasilan itu tidak hanya dilihat dalam upaya memilih alat, pendekatan dan teknik pembelajaran, akan tetapi guru harus membuat strategi pembelajaran yang sesuai dengan materi yang diajarkan guna menghindari kejenuhan siswa dalam proses pembelajaran. Oleh karena itu, tugas utama bagi guru adalah menciptakan suasana belajar yang baik yang dapat memotivasi siswa sehingga prestasi belajar siswa meningkat.

Salah satu upaya untuk membuat siswa memahami konsep abstrak dalam matematika dilakukan dengan menerapkan konsep-konsep tersebut dalam aspekaspek kehidupan yang terkait dengan kehidupan siswa. Penerapan konsep sangat membantu siswa dalam memahami mata pelajaran matematika. Pembelajaran yang mengakomodasi lingkungan siswa, akan meningkatkan motivasi siswa dalam belajar.

Pembelajaran matematika sekarang sering kali tidak belajar penanaman konsep dasar terlebih dahulu akan tetapi langsung belajar penanaman ketrampilan, seharusnya belajar matematika yang tepat yang diajarkan terlebih dahulu penanaman konsep agar siswa mudah memahami dan tidak menjadi ahli penghafal rumus. Belajar Matematika harus dimulai dari konsep yang sederhana bertahap menuju ke tahap yang lebih tinggi. Menurut Pitajeng dalam Lestari (2014:2) Bruner berpendapat bahwa "belajar matematika adalah belajar tentang konsep-konsep dan struktur-struktur matematika yang terdapat di dalam materi yang dipelajari serta mencari hubungan-hubungan antara konsep-konsep dan struktur-struktur matematika"

Diketahui bahwa nilai harian siswa kelas III SD Muhammadiyah 9 Surabaya pada materi pecahan hanya 35,3\% yang mencapai nilai tuntas, sehingga masih belum mencapai ketuntasan yang diharapkan yaitu $80 \%$ siswa memperoleh nilai tuntas. Penyebab utama rendahnya pemahaman siswa terhadap mata pelajaran matematika terjadi karena ketidaktepatan metode pembelajaran yang digunakan, dan masih selalu menggunakan metode klasikal dan ceramah, tanpa diselingi dengan metode yang menantang. Dengan demikian maka perlu adanya perbaikan pembelajaran untuk meningkatkan pemahaman siswa, yaitu melalui penerapan 
teori bruner untuk memperbaiki belajar siswa sehingga kesalahan dalam proses pembelajaran akan segera dianalisa dan diperbaiki.

Hal yang tidak kalah berpengaruh terhadap proses pembelajaran lainnya adalah guru belum menggunakan media dan yang tepat untuk menjelaskan materi pecahan, sehingga pemahaman siswa masih abstrak. Sukayasa (2012:5) pembelajaran menurut teori bruner menyatakan bahwa belajar matematika akan lebih berhasil bila proses pengajarannya diarahkan pada konsep-konsep dan struktur-struktur yang termuat pada bahan ajar .

Dalam proses pembelajaran gurulah yang menentukan keberhasilan seorang siswa maka dari itu butuh pendekatan tertentu agar siswa merasa nyaman dan tanpa paksaan dalam belajar. Salah satu pembelajaran matematika yang berorientasi pada matematisasi pengalaman sehari-hari (mathematic of everyday experience) adalah realistic mathematic education atau yang dikenal di Indonesia Pendidikan Matematika Realistik Indonesia (PMRI). Pernyataan Freundenthal (Wijaya, 2012:20) bahwa "matematika merupakan suatu bentuk aktivitas manusia" melandasi pengembangan Pendidikan Matematika Realistik (Realistic Mathematics Education). Pada PMRI pola pikir siswa dikembangkan dari hal-hal yang bersifat konkrit menuju hal yang abstrak. Aktivitas belajar dilakukan melalui peragaanperagaan yang melibatkan seluruh panca indera.

\section{METODE PENELITIAN}

Penelitian ini termasuk penelitian deskriptif kuantitatif, dimana penelitian ini adalah untuk mendeskripsikan prestasi belajar siswa, aktivitas siswa, aktivitas keterlaksanaan guru dan respon siswa dari data yang sudah diperoleh. Jadi, tujuan penelitian deskriptif adalah untuk membuat penjelasan secara sistematis, faktual, dan akurat mengenai fakta-fakta dan sifat-sifat populasi atau daerah tertentu (Darmawan, 2013:134).

Penelitian ini dilakukan di SD Muhammadiyah 9 Surabaya kelas III semester genap tahun ajaran 2014/2015. Materi yang digunakan adalah materi bangun datar yang disesuaikan dengan kurikulum yang sedang berlaku. Penelitian ini dilaksanakan pada bulan Februari-Maret 2015. 
Subjek dalam penelitian ini adalah siswa kelas III SD Muhammadiyah 9 Surabaya. Banyak Subjek 17 siswa yang terdiri dari 11 siswa perempuan dan 6 siswa laki-laki. Subjek tersebut di bagi menjadi empat kelompok yang heterogen. Setiap kelompok terdiri dari siswa laki-laki dan perempuan, di mana dalam kelompok tersebut terdapat siswa yang memiliki kemampuan tinggi, sedang dan rendah.

Penelitian ini terdiri dari dua variabel: (1) Variabel bebas (X), adalah variabel yang mempengaruhi, dalam hal ini adalah penerapan belajar teori Bruner dengan pendekatan matematika realistik; (2) Variabel terikat (Y), adalah variabel yang dipengaruhi, dalam hal ini adalah prestasi belajar matematika siswa.

Teknik pengumpulan data terdiri tes, observasi, angket dan dokumentasi. (1) Tes adalah suatu alat atau prosedur yang sistematis dan objektif untuk memperoleh data-data atau keterangan-keterangan yang diinginkan tentang seseorang, dengan cara yang boleh dikatakan tepat dan cepat (Arikunto, 2012:46). Tes digunakan untuk memperoleh data sebagai pemahaman siswa; (2) Observasi Pengamatan atau observasi adalah suatu teknik yang dilakukan dengan cara mengadakan pengamatan secara teliti serta pencatatan secara sistematis (Arikunto, 2012:45). Teknik ini digunakan untuk memperoleh data tentang aktivitas siswa dan aktivitas guru; (3) Angket adalah sejumlah pertanyaan tertulis yang digunakan untuk memperoleh informasi dari responden tentang pribadinya, atau hal-hal yang di ketahui. Teknik angket digunakan untuk mengetahui respon siswa terhadap pembelajaran melalui penerapan teori Bruner dengan pendekatan matematika realistik; (4) Dokumentasi yang dimaksud adalah berupa foto-foto dan lembar pengamatan siswa yang diambil opada saat proses pembelajaran. Dokumentasi tersebut menggambarkan tentang perhatian siswa dalam memahami materi yang disampaikan, semangat siswa, keaktifan siswa, kemampuan siswa dalam menemukan gambar yang konkret, keaktifan siswa dalam mengerjakan tugas.

Instrumen yang digunakan pada penelitian ini adalah sebagi berikut: (1) Seperangkat Tes berupa soal pilihan ganda sebanyak 10 butir soal. Tes ini digunakan untuk mengetahui sejauh mana pemahaman siswa tentang materi yang sudah diberikan. Tes diberikaan pada akhir pembelajaran yaitu setelah dua kali 
pertemuan dengan tujuan mengecek pemahaman siswa terhadap pembelajaran yang telah di ikuti. Selain itu tes juga digunakan untuk mengumpulkan data prestasi belajar siswa; (2) Lembar observasi aktivitas siswa dan guru. Lembar observasi aktivitas siswa ini digunakan untuk mengetahui apa yang dilakukan siswa dan guru selama proses pembelajaran melalui penerapan teori Bruner dengan pendekatan matematika realistik; (3) Angket respon siswa digunakan untuk mengetahui tanggapan siswa selama proses pembelajaran melalui penerapan teori Bruner dengan pendekatan matematika realistik berlangsung.

Instrumen yang telah dibuat peneliti sebelum digunakan untuk pengumpulan data terlebih dahulu divalidasi oleh guru SD Muhammadiyah 9 Surabaya selaku guru kelas III dan dosen pembimbing skripsi. Setelah itu di revisi sehingga di peroleh instrumen yang layak.

Penelitian dilakukan secara bertahap, secara garis besar terdapat sebagai berikut:

(a) Tahap persiapan meliputi : menyusun proposal, permohonan izin, penyusunan instrumen dan perangkat.

(b) Tahap pelaksanaan meliputi: validasi, melakukan penelitian, melakukan pembelajaran, melakukan pengamatan aktivitas siswa dan guru, tes dan angket.

(c) Tahap penyelesaian meliputi : analisis data dan penulisan laporan.

Penelitian ini digunakan teknik analisis data persentase. Proses analisis data pada saat dilapangan yaitu saat pelaksanaan kegiatan dan menganalisis data yang sudah terkumpul. Data dari berbagai sumber berupa hasil tes siswa, hasil obsevasi siswa, hasil observasi keterlaksanaan guru dan angket siswa. Teknik analisis data diuraikan sebagai berikut :

1) Teknik Analisis Prestasi Belajar Siswa

$$
\mathrm{TP}=\frac{\text { Skor } \text { Aktual }}{\text { Skor } \text { maksimum Ideal }} \times 100
$$

(Khilwatin, 2010:36)

\section{Keterangan :}

$\mathrm{TP}=$ Tingkat penguasaan

Untuk mengetahui nilai peningkatan prestasi belajar siswa 
Peningkatan Prestasi $=\frac{x_{2}-x_{1}}{x_{1}} \times 100 \% \quad$ (Khilwatin, 2010:36)

Keterangan :

$x_{1}=$ nilai rata-rata pertama (nilai harian)

$x_{2}=$ nilai rata-rata kedua (nilai tes)

Untuk mencari rata-rata dan simpangan baku

$$
S D=\frac{\sum X i^{2}-\left(\sum X i\right)^{2}}{(n-1)}
$$

(Darmadi, 2011:280)

Keterangan :

$\bar{X}=$ Nilai rata-rata

$X i=$ Data ke-i

$n$ = Jumlah data

$S$ = Simpangan baku

2) Teknik analisis aktifan siswa

dengan teknik persentase.

$$
\mathrm{TP}=\frac{n(A)}{n(A S)} \times 100 \%
$$

(Khilwatin, 2010:36)

\section{Keterangan :}

$\mathrm{TP}=$ Tingkat Persentase Aktivitas

$\mathrm{n}(\mathrm{A}) \quad=$ Jumlah Aktivitas yang muncul

$\mathrm{n}(\mathrm{AS}) \quad=$ Jumlah Aktivitas keseluruhan

Adapun tabel penilaian aktivitas siswa sebagai berikut.

Tabel 1: Penialian Aktivitas Siswa

\begin{tabular}{|c|l|c|c|}
\hline No & \multicolumn{1}{|c|}{ Aktivitas Siswa } & $\begin{array}{c}\text { Waktu } \\
\text { Ideal }\end{array}$ & $\begin{array}{c}\text { Batas Interval } \\
\text { Ideal }\end{array}$ \\
\hline 1. & Mendengarkan penjelasan Guru. & $7,14 \%$ & $2-12 \%$ \\
\hline 2. & Menjawab dan bertanya kepada guru. & $7,14 \%$ & $2-12 \%$ \\
\hline 3. & $\begin{array}{l}\text { Memberikan tanggapan pada apa yang disampaikan } \\
\text { guru. }\end{array}$ & $7,14 \%$ & $2-12 \%$ \\
\hline 4. & Mengamati gambar yang diberikan oleh guru. & $10 \%$ & $5-15 \%$ \\
\hline 5. & Mengidentifikasi gambar & $11,4 \%$ & $6-16 \%$ \\
\hline 6. & Menemukan bangun datar disekeliling sekolah & $14,3 \%$ & $9-19 \%$ \\
\hline 7. & $\begin{array}{l}\text { Menggambar dan menulis bangun datar yang sudah } \\
\text { ditemukan pada LKS }\end{array}$ & $14,3 \%$ & $9-19 \%$ \\
\hline 8. & Memeriksa gambar yang diperoleh & $7,14 \%$ & $2-12 \%$ \\
\hline 9. & Melakukan diskusi dengan kelompok & $14,3 \%$ & $9-19 \%$ \\
\hline
\end{tabular}


Penerapan Teori Belajar Bruner Dengan Pendekatan Pendidikan Matematika Realistik

\begin{tabular}{|c|l|c|c|}
\hline No & \multicolumn{1}{|c|}{ Aktivitas Siswa } & $\begin{array}{c}\text { Waktu } \\
\text { Ideal }\end{array}$ & $\begin{array}{c}\text { Batas Interval } \\
\text { Ideal }\end{array}$ \\
\hline 10. & $\begin{array}{l}\text { Siswa mampu menggambar dan menyimpulkan hasil } \\
\text { pengamatan bersama kelompok }\end{array}$ & $7,14 \%$ & $2-12 \%$ \\
\hline 11. & Perilaku yang tidak relevan dengan KBM & 0 & $0-5 \%$ \\
\hline
\end{tabular}

Keterangan :

Diberinilai 4 jika mendekati batas atas interval.

Diberi nilai 3 jika mendekati waktu interval ideal.

Diberi nilai 2 jika ada pada interval tetapi kurang dari waktu interval ideal.

Diberi nilai 1 jika berada pada batas bawah interval.

3) Tingkat aktivitas keterlaksanaan guru

$$
\mathrm{TP}=\frac{n(A)}{n(A S)} \times 100 \%
$$

(Khilwatin, 2010:36)

4) Data Respon siswa

Data respon siswa terhadap pembelajaran melalui penerapan teori Bruner dengan pendekatan pendidikan matematika realistik. Angket dihitung berdasarkan respon siswa yang terdiri dari dua pilihan jawaban "ya" atau "tidak". Setiap jawaban "ya" untuk pernyataan positif bernilai 1, setiap jawaban "tidak" pada pernyataan positif bernilai 0 dan sebaliknya. Untuk menghitung persentase jawaban tersebut adalah dengan rumus :

$$
\text { Presentase respon siswa }=\frac{A}{B} \times 100 \%
$$

(Trianto, 2009:243)

Keterangan :

A : proporsi siswa yang memilih

B : Jumlah siswa (responden)

\section{HASIL PENELITIAN DAN PEMBAHASAN}

\section{Ketuntasan Belajar Siswa}

Data sebelum penelitian yaitu nilai harian siswa pada materi pecahan kelas III SD Muhammadiyah 9 Surabaya. Berdasarkan data yang diperoleh dapat dilihat bahwa 6 siswa atau sebesar 35,3\% tuntas belajar dan 11 siswa atau sebesar 64,7\% siswa tidak tuntas belajar dengan nilai rata-rata 69,4. 
Data setelah penelitian. Setelah penelitian dilaksanakan di SD Muhammadiyah 9 Surabaya siswa diberikan soal tes pada akhir pertemuan untuk mengetahui ketuntasan belajar siswa secara individu. Dari 17 siswa terdapat 15 siswa atau $88,2 \%$ tuntas belajar dan 2 siswa atau $11,8 \%$ tidak tuntas dengan nilai rata-rata 87,6 .

\section{Aktivitas Siswa}

Selama pembelajaran berlangsung aktivitas siswa diamati kemudian dicatat setiap lima menit sekali. Pengamatan aktivitas siswa dilakukan terhadap empat kelompok siswa yang masing-masing siswa terdiri dari enam orang siswa. Adapun data pengamatan aktivitas siswa selama pembelajaran berlangsung adalah sebagai berikut.

Tabel 2: Aktivitas Siswa

\begin{tabular}{|c|c|c|c|c|c|}
\hline \multirow{2}{*}{ No. } & \multirow{2}{*}{ Kategori Aktivitas Siswa } & \multicolumn{2}{|c|}{ Presentase Aktivitas } & \multirow{2}{*}{$\begin{array}{l}\text { Rata- } \\
\text { Rata }\end{array}$} & \multirow{2}{*}{$\begin{array}{l}\text { Presentase } \\
\text { Ideal }\end{array}$} \\
\hline & & Pert ke-1 & Pert ke-2 & & \\
\hline 1. & Mendengarkan penjelasan Guru. & $8,4 \%$ & $10,1 \%$ & $9,25 \%$ & $7,1 \%$ \\
\hline 2. & $\begin{array}{l}\text { Menjawab dan bertanya kepada } \\
\text { guru. }\end{array}$ & $5,9 \%$ & $5,9 \%$ & $5,9 \%$ & $7,1 \%$ \\
\hline 3. & $\begin{array}{l}\text { Memberikan tanggapan pada apa } \\
\text { yang disampaikan guru. }\end{array}$ & $5,9 \%$ & $4,2 \%$ & $5,05 \%$ & $7,1 \%$ \\
\hline 4. & $\begin{array}{l}\text { Mengamati gambar yang } \\
\text { diberikan oleh guru. }\end{array}$ & $13,45 \%$ & $13,9 \%$ & $13,675 \%$ & $10 \%$ \\
\hline 5. & Mengidentifikasi gambar & $6,7 \%$ & $7,1 \%$ & $6,9 \%$ & $10 \%$ \\
\hline 6. & $\begin{array}{l}\text { Menemukan bangun datar } \\
\text { disekeliling sekolah }\end{array}$ & $12,2 \%$ & $13,9 \%$ & $13,05 \%$ & $14,3 \%$ \\
\hline 7. & $\begin{array}{l}\text { Menggambar dan menulis bangun } \\
\text { datar yang sudah ditemukan pada } \\
\text { LKS }\end{array}$ & $16,4 \%$ & $14,7 \%$ & $15,55 \%$ & $14,3 \%$ \\
\hline 8. & Memeriksa gambar yang diperoleh & $6,7 \%$ & $7,1 \%$ & $6,9 \%$ & $7,11 \%$ \\
\hline 9. & $\begin{array}{l}\text { Melakukan diskusi dengan } \\
\text { kelompok }\end{array}$ & $13,45 \%$ & $13,1 \%$ & $13,275 \%$ & $14,3 \%$ \\
\hline 10. & $\begin{array}{l}\text { Siswa mampu menggambar dan } \\
\text { menyimpulkan hasil pengamatan } \\
\text { bersama kelompok }\end{array}$ & $7,1 \%$ & $7,1 \%$ & $7,1 \%$ & $8,7 \%$ \\
\hline 11. & $\begin{array}{l}\text { Perilaku yang tidak relevan } \\
\text { dengan KBM }\end{array}$ & $3,8 \%$ & $2,9 \%$ & $3,35 \%$ & $0 \%$ \\
\hline
\end{tabular}

Berdasarkan data yang diperoleh maka dapat dilihat bahwa siswa dapat melaksanakan semua kategori dengan baik dan siswa aktif saat pembelajaran ber;angsung. 


\section{Aktivitas Keterlaksaan Guru}

Selama pembelajaran berlangsung aktivitas guru diamati untuk mengetahui sejauh mana kegiatan pembelajaran terlaksana sesuai dengan yang tertulis pada RPP. Adapun data pengamatan aktivitas guru selama pembelajaran berlangsung adalah sebagai berikut.

Tabel 3: Aktivitas Keterlaksanaan Guru

\begin{tabular}{|c|l|c|c|c|}
\hline \multirow{2}{*}{ No } & \multicolumn{1}{|c|}{ Kategori Aktivitas Guru } & Presentase Aktivitas & \multirow{2}{*}{ Rata-rata } \\
\cline { 2 - 4 } & Pert ke-1 & Pert ke-2 & \\
\hline 1. & $\begin{array}{l}\text { Guru memberikan salam dan membuka } \\
\text { pembelajaran }\end{array}$ & $100 \%$ & $100 \%$ & $100 \%$ \\
\hline 2. & $\begin{array}{l}\text { Guru mengkondisikan kelas dan siswa pada } \\
\text { situasi belajar yang kondusif }\end{array}$ & $100 \%$ & $100 \%$ & $100 \%$ \\
\hline 3. & $\begin{array}{l}\text { Guru mengadakan apersepsi sebagai } \\
\text { penggali pengetahuan awal siswa }\end{array}$ & $100 \%$ & $100 \%$ & $100 \%$ \\
\hline 4. & Guru menyampaikan tujuan pembelajaran & $100 \%$ & $0 \%$ & $50 \%$ \\
\hline 5. & Guru menunjukkan sebuah gambar & $100 \%$ & $100 \%$ & $100 \%$ \\
\hline 6. & $\begin{array}{l}\text { Guru mengajukan pertanyaan yang terkait } \\
\text { dengan pelajaran dan siswa diberi waktu } \\
\text { untuk menjawab }\end{array}$ & $100 \%$ & $100 \%$ & $100 \%$ \\
\hline 7. & $\begin{array}{l}\text { Guru meminta siswa untuk mencari dan } \\
\text { menggambar secara individu sesuai dengan } \\
\text { LKS yang diberikan }\end{array}$ & $100 \%$ & $100 \%$ & $100 \%$ \\
\hline 8. & $\begin{array}{l}\text { Guru meminta siswa untuk berkelompok } \\
\text { dan mendiskusikan mengenai apa yang } \\
\text { diperoleh dari pekerjaan individu }\end{array}$ & $100 \%$ & $100 \%$ & $100 \%$ \\
\hline 9. & $\begin{array}{l}\text { Guru meminta kelompok untuk berbagi atau } \\
\text { bekerjasama mengenai apa yang telah } \\
\text { mereka bicarakan }\end{array}$ & $100 \%$ & $100 \%$ & $100 \%$ \\
\hline 10 & $\begin{array}{l}\text { Menugaskan kelompok yang tidak sedang } \\
\text { melapor untuk menanggapi dengan bertanya } \\
\text { dan memberikan komentar }\end{array}$ & $100 \%$ & $100 \%$ & $100 \%$ \\
\hline 11. & $\begin{array}{l}\text { Membimbing siswa untuk menyimpulkan } \\
\text { pembelajaran }\end{array}$ & $100 \%$ & $100 \%$ & $100 \%$ \\
\hline 12. & Tindak lanjut dan mengucapkan salam & $0 \%$ & $100 \%$ & $50 \%$ \\
\hline & \multicolumn{3}{|l|}{ Jumlah } & $91,6 \%$ \\
\hline
\end{tabular}

Aktivitas guru dapat dilihat bahwa guru telah melaksanakan pembelajaran dengan baik sesuai dengan RPP, setiap kategori sudah dilaksanakan meskipun ada kategori yang terlewati pada pertemuan pertama dan kedua. Pada pertemuan pertama guru tidak melaksanakan kategori tindak lanjut dan mengucapkan salam. Pada pertemuan kedua guru tidak melaksanakan kategori menyampaikan tujuan pembelajaran. Terlihat bahwa 91,6\% guru melaksanakan sesuai dengan rencana pelaksanaan pembelajran (RPP). 


\section{Respon Siswa}

Setelah dilakukan pembelajaran siswa diminta untuk mengisi angket respon siswa untuk mengetahui ketertarikan siswa terhadap pembelajaran yang telah diikuti. Adapun hasil respon siswa adalah sebagai berikut.

Tabel 3: Respon Siswa Terhadap pemebelajaran Penerapan Teori Belajar Bruner Dengan Pendekatan Pendidikan Matematika Realistik.

\begin{tabular}{|c|l|c|c|}
\hline \multirow{2}{*}{ No } & \multicolumn{1}{|c|}{ Pernyataan } & \multicolumn{2}{|c|}{ Jawaban } \\
\cline { 3 - 4 } & & Ya & Tidak \\
\hline 1. & Menyukai pelajaran matematika hari ini. & 17 & 0 \\
\hline 2. & Memahami materi pelajaran hari ini. & 16 & 1 \\
\hline 3. & Tidak merasa takut dengan pelajaran matematika kali ini & 18 & 0 \\
\hline 4. & $\begin{array}{l}\text { Diawal pembelajaran, guru meminta untuk mengamati suatu } \\
\text { benda. }\end{array}$ & 18 & 0 \\
\hline 5. & $\begin{array}{l}\text { Guru memberi pertanyaan yang membangun rasa ingin tahu } \\
\text { saya }\end{array}$ & 16 & 1 \\
\hline 6. & Guru memberi kesempatan saya untuk bertanya & 17 & 0 \\
\hline 7. & $\begin{array}{l}\text { Guru memberi motivasi siswa untuk menyelesaikan } \\
\text { permasalahan yang diberikan. }\end{array}$ & 17 & 0 \\
\hline 8. & $\begin{array}{l}\text { Guru membimbing siswa ketika siswa merasa bingung saat } \\
\text { proses pembelajaran. }\end{array}$ & 17 & 0 \\
\hline 9 & $\begin{array}{l}\text { Guru membimbing untuk mengambil kesimpulan materi } \\
\text { pelajaran matematika. }\end{array}$ & 17 & 0 \\
\hline 10 & $\begin{array}{l}\text { Guru memberikan kesempatan untuk saling mengemukakan } \\
\text { pendapat mengenai materi pelajaran matematika. }\end{array}$ & 14 & 3 \\
\hline
\end{tabular}

Berdasarkan Tabel respon siswa dapat ditunjukkan bahwa siswa memberikan respon positif lebih besar dari pada respon negatif. Banyak siswa yang menyukai cara pembelajaran melalui penerapan teori Bruner dengan pendekatan matematika realistik. Dapat dikatakan bahwa siswa menyukai penerapan teori Bruner dengan pendekatan matematika realistik beserta guru yang mengajar.

\section{SIMPULAN}

Berdasarkan analisis data dan hasil pembahasan pada BAB IV, maka penelitian ini dapat diambil simpulan sebagai berikut.

1. Prestasi belajar siswa kelas III SD Muhammadiyah 9 Surabaya sesudah dilakukan pembelajaran melalui penerapan teori Bruner dengan pendekatan pendidikan matematika realistik mengalami peningkatan dari nilai rata-rata 


\section{Penerapan Teori Belajar Bruner Dengan Pendekatan Pendidikan Matematika Realistik}

69,4 menjadi 87,6. Dengan demikian peningkatan prestasi belajar sebesar $26,22 \%$.

2. Aktivitas siswa kelas III SD Muhammadiyah 9 Surabaya sesudah dilakukan pembelajaran melalui penerapan teori Bruner dengan pendekatan pendidikan matematika realistik dapat membangkitkan keaktivan siswa sebesar 87,4\%.

3. Aktivitas guru kelas III SD Muhammadiyah 9 Surabaya dalam pelaksanaan pembelajaran melalui penerapan teori Bruner dengan pendekatan pendidikan matematika realistik terlaksana sebesar 91,6\%.

4. Siswa kelas III SD Muhammadiyah 9 Surabaya merespon dengan baik pembelajaran melalui penerapan teori Bruner dengan pendekatan matematika realistik sebesar 98,03\% dan respon siswa terhadap pembelajaran yang disampaikan guru ini sebesar 96,64\%. Jumlah respon siswa terhadap penerapan teori Bruner dengan pendekatan pendidikan matematika realistik sebesar $96,7 \%$.

\section{DAFTAR PUSTAKA}

Arikunto, Suharsimi. 2012. Dasar-Dasar Evaluasi Pendidikan. Jakarta : Bumi Aksara.

Darmadi, Hamid. 2011. Metode Penelitian Pendidikan. Bandung: Alfabeta.

Darmawan. 2013. Metode Penelitian Kuantitatif. Bandung : PT Remaja Rosdakarya. Mrnyelesaikan Soal Cerita Pecahan (Skripsi tidak Dipublikasikan). Surabaya:Universitas Negeri Surabaya.

Karim, Asrul. 2011. "Penerapan Metode Penemuan Terbimbing Dalam Pembelajaran Matematika Untuk Meningkatkan Pemahaman Konsep dan Kemampuan Berfikir Kritis Siswa SD”. Jakarta:Edisi khusus No.1 ISSN 1412-565X.

Khilwatin, Tina. 2014. Meningkatkan Prestasi Belajar Matematika Siswa Kelas VII SMP Muhammadiyah 2 Surabaya Melalui Scientific Aproach Dengan

Discovery Learning Model (Skripsi tidak Dipublikasikan). Surabaya: Universitas Muhammadiyah Surabaya.

Trianto. 2009. Mendesain Model Pembelajaran Inovatif-Progresif. Jakarta: Kencana.

Sukayasa. 2012. Penerapan Pendekatan konstruktivis Untuk Meningkatkan Pemahaman Siswa SD Karunadipa Palu Pada Konsep Volume Bangun Ruang. Jurnal Peluang. Vol 1, Nomor 1, Oktober 2012, ISSN:2302-5158.

Warli. 2012. Pembelajaran Matematika Realistik Geometri Kelas IV MI. Tersedia pada

http:/journal.Unirow.ac.id/ojs/files/journal/2/articles/4/public/JURNALWARLI-4.pdf. 
Ervayani $^{1}$, Iis Holisin ${ }^{2}$, Shoffan Shoffa ${ }^{3}$

Wijaya, Ariayadi. 2012. Pendidikan Matematika Realistik. Yogyakarta : Graha Ilmu. 